\title{
Selection and Evaluation of Suitable Tree Species in Drought and High-dust Coal Base in Northwest China
}

\section{Xiaofang Zhu}

Ningxia University

\section{Bing Cao}

School of Agriculture, Ningxia University

XING WANG ( $\square$ Xingwang1984@foxmail.com )

Helan Mountain West Road, Xixia District, Yinchuan, Ningxia, 750021, China

\section{Siming Zhao}

School of Agriculture, Ningxia Univesity

\section{Hao Zhang}

Ningxia University

\section{Deping Gao}

Ningxia University

\section{Yongfeng Duan}

Ningxia University

\section{Research}

Keywords: coal base, afforestation tree species, drought resistance, dust resistance, evaluation index system

Posted Date: October 15th, 2020

DOI: https://doi.org/10.21203/rs.3.rs-91189/v1

License: (c) (1) This work is licensed under a Creative Commons Attribution 4.0 International License. Read Full License 
3

4

5

6

7 8
High-Dust Coal Base in Northwest China

4

.

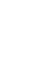

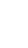

(
*1 Corresponding Author: 489 Helan Mountain West Road, Xixia District, Yinchuan, Ningxia, 750021, China
$*^{2}$ Corresponding Author: 489 Helan Mountain West Road, Xixia District, Yinchuan, Ningxia, 750021, China Phone:86-0951-2061811, Email: Xingwang1984@foxmail.com




\section{Abstract}

To select drought-resistant and dust-tolerant tree species suitable for being planted in a drought-ridden and high-dust coal base in northwest China, we used nine tree species to determine the growth status, biomass, harm index, and photosynthetic characteristics under drought and highly dusty stress conditions. The results showed that in the drought resistance index system, their cumulative contribution rate reached 98.1\%, and the drought resistance order was Ammopiptanthus mongolicus $>$ Hedysarum scoparium $>$ Sabina vulgaris $>$ Caragana korshinskii $>$ Ulmus pumila $>$ Amorpha fruticosa $>$ Caryopteris mongholica $>$ Tamarix chinensis $>$ Elaeagnus angustifolia. In the dust resistance index system, the cumulative contribution rate reached $95.2 \%$. The dust resistance order was Caragana korshinskii $>$ Amorpha fruticosa $>$ Sabina vulgaris $>$ Hedysarum scoparium $>$ Tamarix chinensis $>$ Ammopiptanthus mongolicus $>$ Ulmus pumila $>$ Caryopteris mongholica $>$ Elaeagnus angustifolia. In the drought and dust resistance comprehensive index system, 14 indices (shoot length, stomatal conductance, and POD) had larger weights and the cumulative contribution of comprehensive indices reached $100 \%$. The drought and dust resistance order of the test tree species was Caragana korshinskii $>$ Ulmus pumila $>$ Amorpha fruticosa $>$ Sabina vulgaris $>$ Caryopteris mongholica $>$ Ammopiptanthus mongolicus $>$ Hedysarum scoparium > Tamarix chinensis $>$ Elaeagnus angustifolia. These results provided a reference for the selection of suitable greening tree species in accordance with local conditions in drought-mining areas. 
1 Keywords: coal base; afforestation tree species; drought resistance; dust resistance;

2 evaluation index system

3

4

5

\section{Introduction}

Drought is the main factor limiting plant growth in northwest China (Li et al., 2010; Na et al., 2018; Zhao et al., 2018). The precipitation in northwest China is always low, which causes dry air and soil dehydration, resulting in a water deficit in plants and affecting normal growth and development of plants (Wang et al., 2015). About onethird of China's land is in arid regions, and drought and lack of water resources are the most important factors restricting economic and social development as well as the construction of an ecological environment in these regions (Ji et al., 2006; Li et al., 2010). Dry climate, low annual precipitation, and severe evaporation severely restrict the growth and development of plants (Li et al., 2010; Sun et al., 2003; Wang et al., 2015), and thus, the research and application of drought-resistant plants is particularly important. Drought-resistant plants are plants that can tolerate long-term drought conditions and grow normally (Chang et al., 2018; Li et al., 2010;). The drought resistance mechanisms of drought-resistant plants usually are studied from the morphological structure and physiological and biochemical indices of plants $(\mathrm{Hu}$ et al.,1998; Liu et al.,1994; Shan et al.,1999).

There are many studies on the dust resistance of plants (Nurmamat et al., 2017; Shah et al., 2018; Wang et al., 2015; Zhang et al., 2015). Most of these studies have focused on the dust retention of urban and park greening tree species (Joshi et al., 2007; 
1 Li et al., 2016; Lin et al., 2014; Tang 2017; Wang et al.,2015) and some studies have

2 focused on urban air pollution control, including the function and mechanism of urban

3 greening trees to purify air and the dust retention function of urban greening tree species

$4 \quad$ (Beckett et al., 1998; Prajapati and Tripathi 2008; Wang et al., 2015; Zheng 2013; Zhang

5 et al., 2015(a); Zhang et al., 2015(b)). Highly concentrated airborne particulate matter,

6 sulfur dioxide $\left(\mathrm{SO}_{2}\right)$, and nitric oxide $\left(\mathrm{NO}_{\mathrm{x}}\right)$ seriously harm human health, causing

7 respiratory symptoms and increasing the risk of obstructing the lungs (Burtraw et al.,

8 2003; Fan 2014). Additionally, the strong scattering effect of fine particles decreases

9 air visibility and induces hazy weather (Shang et al., 2011; Wu 2012). Therefore, in

light of new problems introduced by air pollution, research on the dust resistance of

plants has been continuously expanded and deepened in recent years (Nurmamat et al., 2017; Salmond et al., 2013; Tang 2017; Zhang et al., 2017; Zheng 2013). These studies have enriched the focus of plant selection from different perspectives. The dust pollution in mining areas is much higher than that in cities, but studies have rarely focused on the dust resistance of tree species selected in mining areas. vegetation construction in northwest China (Li et al., 2010; Na et al., 2018; Wang et al., 2015; Zhao et al., 2018). Coal bases in arid areas require drought-resistant tree species 
1 dust resistance includes dust retention and antidusting (Lin et al., 2014; Losfeld et al.,

2 2014; Schleicher et al., 2011; Wang 2011; Zhang 2016). Therefore, afforestation tree

3 species need to have both drought resistance and dust resistance. Few studies have been

4 conducted on the election of tree species in arid coal mine areas in northwest China,

5 especially in high-dust sites in coal mine areas. Therefore, this study observed multiple

6 growth and physiological indices to analyze the drought resistance and dust resistance.

7

\section{Materials and Methodology}

2.1. Overview of the test area

We conducted a dust resistance test at the Yangchangwan Coal Mine of Shenhua Ningxia Coal Industry Group. We tested drought resistance at a nearby test farm where the east longitude is $106^{\circ} 23^{\prime} 75.87^{\prime \prime}-106^{\circ} 59^{\prime} 67.57^{\prime \prime}$, the northern latitude is $38^{\circ} 00^{\prime} 42.79^{\prime \prime}-38^{\circ} 23^{\prime} 01.88^{\prime \prime}$, and the altitude is $1,117-1,232 \mathrm{~m}$. The climate is semi-arid desert continental monsoon climate, and diurnal temperature variation is large. In 2018, average annual temperature was $8.8^{\circ} \mathrm{C}$, average annual rainfall was $206.2 \mathrm{~mm}$, average frost-free period was $167 \mathrm{~d}$, and average annual evaporation was 1,470.1 $\mathrm{mm}$.

2.2. Test materials and methods

This study adopted the seedling of Caragana korshinskii Kom., Tamarix chinensis Lour., Amorpha fruticosa Linn., Hedysarum scoparium Fisch. etMey., Ammopiptanthus mongolicus, Caryopteris mongholica Bunge, Sabina vulgaris Ant., Ulmus pumila L., and Elaeagnus angustifolia Linn. Principal component analysis (PCA) was used to calculate the weight of each index and to establish a tree drought resistance evaluation index system (Xie and Hu 2016; Guo and Wang 2018). 
Among the early potted seedlings, we selected one-year robust potted seedlings

with basically consistent growth vigor. The size of the test pot was upper diameter * lower diameter $*$ height $=580 \mathrm{~mm} * 450 \mathrm{~mm} * 520 \mathrm{~mm}$. The potting soil was simulated earthing soil of waste rock field from the Lingwu Yangchangwan Coal Mine (its physicochemical properties are shown in Table 1). In April 2018, we planted the selected tree species in the coal-mining areas for the drought resistance and dust retention test. The detailed planting methods are shown in Fig. 1

In the drought resistance test, we conducted progressive water stress treatment using the pot-water control method and adopted single-factor design. We set up a natural drought treatment group and control group. All plants were fully irrigated three days before the test to ensure that the soil in each pot was saturated. We stopped watering the plants in the drought treatment group after the test, and watered these plants again 30 days after drought stress. The plants in the control groups were watered every seven days. For the dust resistance test, we selected the dust-contaminated coalmining areas (waste rock field) for the potted species. The dust retention per unit area was $1.08-2.76 \mathrm{~g} / \mathrm{m}^{2} /$ week, and the plants were watered every seven days. After rainfall $(>15 \mathrm{~mm})$, we measured the relevant indices in dust resistance and drought resistance tests every seven days. We replicated the test with 10 pots of each tree species.

\subsection{Measurement indices}

2.3.1 Growth indices and biomass

At the beginning and end of the drought resistance and dust retention test, we measured growth indices (plant height, ground diameter, shoot length, and crown 
1 breadth) to calculate the net growth. We dug out three whole plants out to measure

2 biomass of the stems, leaves, and roots, and we calculated the water content of leaves

3 (= (leaf fresh mass-leaf dry mass) / leaf fresh mass), plant water content, leaf biomass

4 ratio (= leaf dry mass / plant dry mass), root biomass ratio, stem biomass ratio (= stem

5 dry mass / plant dry mass), root shoot ratio (root dry mass / upper ground dry mass),

6 and the length of the main root system.

$7 \quad$ 2.3.2 Main indices of drought resistance and dust resistance

We measured 28 drought-resistant physiological indices, including superoxide dismutase (SOD), peroxidase (POD), catalase (CAT), and other enzyme activities; photosynthetic characteristic parameters; water consumption; leaf water saturation deficit; and 20 dust resistance indices, including dust retention per unit leaf area, dust retention per unit leaf weight, stomatal conductance, main root system length, transpiration rate, photosynthetic rate, harm index, and water use efficiency. the amount of dust retention by the cleaning method. We measured leaf area with a where $d_{f}$ is the amount of dust retention per unit fresh leaf weight $(\mathrm{g} / \mathrm{g}) ; W_{f}$ is the total leaf fresh weight of the sample $(\mathrm{g})$; and $M$ is the total dust retention of all leaves of the samples (g). 


\subsubsection{Harm index}

To observe the impact of dust retention on plant morphology, we established a classification standard for leaf damage caused by dust retention (see Table 2). In the dust resistance test, we investigated and classified 10 leaves of different orientations (east, west, south, north) and parts (upper, middle, and lower) of each tree species according to the following harm degree and calculated their harm indices:

$$
\text { Harm index }=\frac{\sum(\text { Harm grade leaves } * \text { Harm grade representative value })}{(\text { Total investigated leaves } * \text { Highest harm grade value })} * 100 \% \text {. }
$$

Table 3 shows the harmed symptoms and grades of leaves from different tree species after dust retention, and the grades of the harmed leaves from left to right are 0 , 1, 2, 3, 4, and 5. Sabina vulgaris was less affected by dust retention and only showed harmed symptoms of grade 0 and grade 1.

\subsubsection{Photosynthetic physiology}

At the beginning, middle, and end periods of the test, with the TARGAS-1 portable photosynthesis analyzer (PP Systems, Amesbury, MA, USA), we randomly selected three leaves of different plants on the sunny side from 9:00 to 11:00 a.m. on sunny days to measure the photosynthetic physiology of different tree species. The indices included transpiration rate, stomatal conductance, photosynthetic rate, intercellular carbon dioxide $\left(\mathrm{CO}_{2}\right)$ concentration, and water use efficiency.

2.4 Data processing and analysis

The drought resistance coefficient and dust resistance coefficient were calculated, and then the reverse indices were converted into positive indices (Liu et al., 2014 and Liu 2009) and SPSS 21.0 was applied to process the data. 
(1) Coefficients of drought and dust resistance:

Drought resistance coefficient $=($ measurement value of drought stress group/measurement value of control group) $* 100 \%$.

Dust resistance coefficient $=$ (measurement value of dust retention treatment group/ measurement value of control group) $* 100 \%$.

(2) Calculation of membership function value $U\left(X_{j}\right)$ of each comprehensive index (Zhang et al., 2014):

$$
U\left(X_{j}\right)=\left(X_{j}-X_{\min }\right) /\left(X_{\max }-X_{\min }\right) \mathrm{j}=1,2 \cdots \cdot \mathrm{n},
$$

where $\mathrm{X}_{j}$ represents the $j$-th comprehensive index, and $\mathrm{X}_{\max }$ and $\mathrm{X}_{\min }$ represent the maximum and minimum values of the $j$-th comprehensive index, respectively.

(3) Calculation of weights of various comprehensive indices (Dong et al., 2016; Shi et al., 2015):

$$
W_{j}=\frac{p_{j}}{\sum_{j=i}^{n} p_{j}} \mathrm{j}=1,2 \cdots \mathrm{n}
$$

where $W_{j}$ represents the importance degree of the $j$-th comprehensive index in all the comprehensive indices, that is, weight; and $P_{j}$ represents the contribution rate of the $j$ th comprehensive index of each tree species obtained through principal component analysis.

(4) Comprehensive drought and dust resistance of each tree species:

$$
\mathrm{D}=\sum_{j=1}^{n} U\left(X_{j}\right) \times W_{j} \mathrm{j}=1,2 \cdots \mathrm{n},
$$

where the $\mathrm{D}$ value refers to the comprehensive evaluation value of drought resistance or dust resistance obtained by a comprehensive index evaluation of each tree species under drought stress or dust retention stress (Zhu et al., 2011). 
3. Results and Analysis

3.1 Screening and evaluation of drought resistance indices of tree species

3.1.1 Establishment of evaluation index system for drought resistance of tree species

Table 4 shows the weight of each index and drought resistance evaluation index system. The greater the weight was, the greater the importance of the index. Among these indices, water consumption, RWC (relative water content), RWD (relative water deficit), conductivity, SOD content, and POD content had relatively large weights resistance of tree species.

\subsubsection{Comprehensive evaluation of drought resistance of tree species}

Table 5 shows the drought resistance coefficients of 28 individual indicators of nine tree species. The contribution rates of the first seven comprehensive indices were $26.9 \%, 18.9 \%, 16.4 \%, 12.3 \%, 10.9 \%, 7.1 \%$, and $5.3 \%$, and their cumulative contribution rate reached $98.1 \%$. Thus, we transformed 28 individual indicators into new and independent comprehensive indicators $C_{I I}-C_{I 7}$.

We used equations (3) and (4) to obtain the membership function values and weights of the seven comprehensive indices, and then used equation (5) to obtain the D value of the comprehensive evaluation of drought resistance. According to the $\mathrm{D}$ value and ranking, the order of the drought resistance of nine tree species was as follows (Table 6): Ammopiptanthus mongolicus $(0.6750)>$ Hedysarum scoparium $(0.6265)>$ Sabina vulgaris $(0.62633)>$ Caragana korshinskii $(0.6053)>$ Ulmus pumila $(0.5952)>$ 
1 Amorpha fruticose (0.5357) > Caryopteris mongholica (0.5276) > Tamarix chinensis

$2(0.4817)>$ Elaeagnus angustifolia (0.1935). Ammopiptanthus mongolicus and

3 Hedysarum scoparium had stronger drought resistance; Elaeagnus angustifolia and

$4 \quad$ Tamarix chinensis had less drought resistance.

5

$6 \quad 3.2$ Screening and evaluation of dust resistance indices of tree species

$7 \quad$ 3.2.1 Establishment of evaluation index system for dust resistance of tree species

Under a dust environment, tree species reflect their adaptability through intuitive

changes in morphology and structure and biomass allocation. The amount of dust retention on the leaves indirectly reflects the pollution of the surrounding air, and the harm indices of the leaves more intuitively reflect the harmed situation of the tree species by the dust retention. Dust retention per unit leaf area, dust retention per unit leaf weight, stomatal conductance, main root system length, transpiration rate, photosynthetic rate, harm index, water use efficiency, and root biomass ratio had a relatively high weight $(>0.05)$ and could be used as the main indices to evaluate the dust resistance of tree species (Table 7).

3.2.2 Comprehensive evaluation of dust resistance of tree species

The dust resistance coefficients were calculated and the results showed that the contribution rates of the first six comprehensive indices were $30.5 \%, 18.8 \%, 16.1 \%$, $13.4 \%, 9.3 \%$, and $7.1 \%$, and the cumulative contribution rate reached $95.2 \%$ (Table 8 ). Thus, we transformed 20 individual indicators into new and independent comprehensive indicators $C I_{1}-C_{6}$. Table 9 shows the $\mathrm{D}$ value of the comprehensive evaluation of dust resistance: Caragana korshinskii $>$ Amorpha fruticosa $>$ Sabina 
1 vulgaris $>$ Hedysarum scoparium $>$ Tamarix chinensis $>$ Ammopiptanthus mongolicus $>$

2 Ulmus pumila > Caryopteris mongholica > Elaeagnus angustifolia. Caragana

3 korshinskii and Amorpha fruticosa had stronger dust resistance and the D value reached

$4 \quad 0.5782$ and 0.5139 , respectively. The less dust-resistant species were Caryopteris

$5 \quad$ mongholica and Elaeagnus angustifolia.

3.3 Comprehensive evaluation of drought and dust resistance

The drought resistance and dust resistance indices included seven primary indices and 48 secondary indices. Among the indices, shoot length (dust retention), stomatal conductance (dust retention), crown breadth (dust retention), POD content (drought resistance), stem biomass ratio (dust retention), and transpiration rate (drought resistance), SOD content (drought resistance), dust retention per unit weight (dust retention), photosynthetic rate (dust retention), water consumption (drought resistance), malondialdehyde (MDA) content (drought resistance), intercellular $\mathrm{CO}_{2}$ concentration (drought resistance), CAT content (drought resistance), and survival rate (drought resistance) had a relatively large weight $(>0.03)$. We used these indices as the main indices to evaluate drought resistance and dust resistance of tree species. $18.562 \%, 14.483 \%, 13.197 \%, 10.318 \%, 10.095 \%, 6.726 \%$, and $4.217 \%$, and their cumulative contribution rate reached $100 \%$. Thus, we transformed 48 individual indicators into new and independent comprehensive indicators $C_{1}-C I_{9}$. The $\mathrm{D}$ value of the comprehensive evaluation of drought and dust resistance of each tree species was 
1 Caragana korshinskii $>$ Ulmus pumila $>$ Amorpha fruticosa $>$ Sabina vulgaris $>$

2 Caryopteris mongholica $>$ Ammopiptanthus mongolicus $>$ Hedysarum scoparium $>$

3 Tamarix chinensis $>$ Elaeagnus angustifolia. Caragana korshinskii and Ulmus pumila

4 had stronger drought and dust resistance (Table 10).

\section{Discussion}

The selection of afforestation tree species has been an important subject in forestry research. It generally is believed that because of the drought and water shortage in northwest China, tree species with good drought resistance are the key to overcoming tree growth and survival under water shortage conditions. This view is not incorrect, but not all problems can be solved with trees that have drought resistance or with irrigation, including air pollution resistance. In some cases, trees grow normally without serious pollution but cannot grow normally and even may die in certain cases of air pollution even if the irrigation water is sufficient. In such cases, the anti-pollution capacity of a tree species needs to be given priority.

This research introduced multiple variables while also incorporating the complex factors into several principal components, which simplified the problem and obtained more scientific and effective data information. As a result, this research better overcame the subjectivity of artificially determined index weights (Yu et al.,2018; Zhou et al., 2016). D value is a dimensionless comprehensive evaluation constant of each tree species. This evaluation was relatively objective and reliable. The PCA method and membership function has offered advantages for the selection of suitable tree species 
1 for afforestation in complex environments, and it is worth learning and applying. Tree

2 species with strong drought resistance should be planted in environments with light dust

3 in coal bases, those with better dust resistance could be selected for environments with

4 serious dust and irrigation conditions, and those with good drought resistance and dust

5 resistance could be planted in environments with high dust and water shortage.

6 Although this experimental study was completed under the dust conditions of arid coal

7 bases, it also had certain reference application value for the selection of tree species

8 under the dust environment of other mining areas with the same aridity.

9

\section{Conclusions}

According to the results of this study, we drew the following conclusions.

1. Water consumption, RWC, RWD, conductivity, SOD content, and POD content had a relatively larger weight $(>0.05)$ and therefore could be used as the main indices for the evaluation index system of drought resistance of tree species. The order of drought resistance was Ammopiptanthus mongolicus $>$ Hedysarum scoparium $>$ Sabina vulgaris $>$ Caragana korshinskii $>$ Ulmus pumila $>$ Amorpha fruticosa $>$ Caryopteris mongholica $>$ Tamarix chinensis $>$ Elaeagnus angustifolia.

2. Dust retention per unit leaf area, dust retention per unit leaf weight, stomatal conductance, main root system length, transpiration rate, photosynthetic rate, harm index, water use efficiency, and root biomass ratio had a relatively high weight $(>0.05)$ and therefore could be used as the main indices to evaluate the dust resistance of tree species. The order of dust resistance was Caragana korshinskii $>$ Amorpha fruticosa $>$

Sabina vulgaris $>$ Hedysarum scoparium $>$ Tamarix chinensis $>$ Ammopiptanthus 
mongolicus $>$ Ulmus pumila $>$ Caryopteris mongholica $>$ Elaeagnus angustifolia.

3. Shoot length (dust retention), stomatal conductance (dust retention), crown breadth (dust retention), POD content (drought resistance), stem biomass ratio (dust retention), transpiration rate (drought resistance), SOD content (drought resistance), dust retention per unit weight (dust retention), photosynthetic rate (dust retention), water consumption (drought resistance), MDA content (drought resistance), intercellular $\mathrm{CO}_{2}$ concentration (drought resistance), CAT content (drought resistance), and survival rate (drought resistance) had a relatively large weight $(>0.03)$ and could be used as the main indices for the comprehensive index system of drought resistance and dust resistance. The order of comprehensive capacity of drought resistance and dust resistance was Caragana korshinskii $>$ Ulmus pumila $>$ Amorpha fruticose $>$ Sabina vulgaris $>$ Caryopteris mongholica $>$ Ammopiptanthus mongolicus $>$ Hedysarum scoparium $>$ Tamarix chinensis $>$ Elaeagnus angustifolia.

\section{Reference}

Baidourela A, Halik U, Aishan T, Abliz A, Welp M (2015) Dust Retention Capacities of Urban Trees and the Influencing Factors in Aksu, Xinjiang, China, Journal of Desert Research, 35(2):322-329.

Beckett KP, Freer-Smith PH, Taylor G (1998) Urban woodlands: their role in reducing the effects of particulate pollution. Environmental pollution.99(3), 347-360.

Burtraw D, Krupnick A, Palmer K, Paul A, Toman M, Bloyd C (2003) Ancillary benefits of reduced air pollution in the US from moderate greenhouse gas 
mitigation policies in the electricity sector. Journal of Environmental Economics and Management, 45(3), 650-673.

3 Chang QS, Zhang LX, Wang JZ (2018) Effects of drought stress and rewatering on physiological indices of four Paeonia lactiflora cultivars and evaluation of their drought resistance. Journal of Nanjing Forestry University (Natural Science Edition), 42(06):044-50.

Dong X, Yan X, Li W, Liu R, Gu W (2016) Tissue-specific expression profiling of seedling stage in early-maturity mutant induced by carbon ion beam in sweet sorghum. J Agri Sci, 9, 49-63.

Fan CY (2014) The analysis of economic Losses for the effect of main air pollutant on resident health in city of Beijing. North China Electric Power University.

Guo XQ, Wang YC (2018) Quality of Lycium barbarum in East Hexi Corridor Region: Comprehensive Assessing Index Construction. Chinese Agricultural Science Bulletin.34(22):66-71.

Hu TT, Kang SZ (2005) The compensatory effect in drought resistance of plants and its application in water-saving agriculture. Acta Ecologica Sinica, (4): 885-891.

Hu XS, Wang SJ (1998) The research on physiological water resistant and drought endurance of forest tree forest species. SCIENTIA, 3 (42): 77-89. 
1 Ji KS, Sun ZY, Fang Y (2006) Research Advance on the Drought Resistant in Forest. Journal of Nanjing Forestry University (Natural Science Edition), 30 (6): 123128.

Joshi SC, Chandra S, Palni LMS (2007) Differences in photosynthetic characteristics and accumulation of osmoprotectants in saplings of evergreen plants grown inside and outside a glasshouse during the winter season. Photosynthetica, 45(4):594-600.

Li L, Jia ZQ, Zhu YJ (2010) Research Advances on Drought Resistance Mechanism of Plant Species in Arid Area of China. Journal of Desert Research (5): 1053-1059.

Li H, Wang GH, Zhang Y, Zhang WK (2016) Morphometric traits capture the climatically driven species turnover of 10 spruce taxa across China. Ecology and evolution.

Lin YK, Li QS, Li XF (2014) Pyrolysates distribution and kinetics of Shenmu long flame coal. Energy Conversion Management, 86:428-434.

Liu JW, Li YR, Wang SJ (1994) Relations between the net photosynthesis and drought tolerance in six polar clones. SCIENTIA, 30 (1): 83-87.

Liu DL, Peng SB, Sun HM (2014) Comprehensive Evaluation on Drought Resistance of Early Fruiting Walnut Cultivars. Acta Horticulturae Sinica, 41(5), 967-974.

Liu XH (2009) Necessity and software operation of positive management in factor analysis. Journal of Chongqing Institute of technology, 23(9), 152-155. 
Losfeld G, L'huillier L, Fogliani B, Jaffré T, Grison C (2015) Mining in New Caledonia: environmental stakes and restoration opportunities. Environmental Science and Pollution Research, 22(8), 5592-5607.

Messina FJ, Durham SL (2002) Trade-off between plant growth and defense, A comparison of sagebrush populations. Oecologia, 131 (1) 43- 51.

Na Z, Jiang DM (2018) Study of the drought resistance of thirteen sand-fixing plants in Horqin Sand Land, China. International Journal of Agriculture and Biology, 20, $1717-1724$.

Nurmamat K, Halik Ü, Baidourela A, Nasirdin N (2017) Dust Retention Capacity of Common Tree Species for Urban Greening in Aksu City, Northwest China. Scientia Silvae Sinicae, 53(1):101-107.

Prajapati SK, Tripathi BD (2008) Seasonal variation of leaf dust accumulation and pigment content in plant species exposed to urban particulates pollution. Journal of environmental quality, 37(3), 865-870.

Salmond JA, Williams DE, Laing G (2013) The influence of vegetation on the horizontal and vertical distribution of pollutants in a street canyon. Science of the Total Environment, 443: 287-298.

Schleicher NJ, Norra S, Chai F, Chen Y, Wang S, Cen K (2011) Temporal variability of trace metal mobility of urban particulate matter from Beijing-A contribution to health impact assessments of aerosols. Atmospheric Environment, 45(39), 7248-7265. 
Shan L, Su P, Guo LK (1999) The response of different crops to drying wetting cycle in field. Acta Botanica Boreali-occidentalia Sinica, 20 (2): 164- 170.

Shah K, Ul Amin N, Ahmad I, Ara G (2018) Impact assessment of leaf pigments in selected landscape plants exposed to roadside dust. Environmental Science and Pollution Research, 25(23), 23055-23073.

Shang Q, Li ZH, Yang J (2011) Size Distributions of Aerosol Particles and the Impact on Visibility in Winter of Nanjing. Chinese Journal of Environmental Science, 32(9):2750-2760.

Shi HM, Zhang HY, Yang B (2015) Effects of Low Temperature Stress on the Content of MDA, SOD and POD Activity in Sorghum Seedlings. Chinese Agricultural Science Bulletin,31(18):74-79.

Sun B, Zhou S, Zhao Q (2003) Evaluation of spatial and temporal changes of soil quality based on geostatistical analysis in the hill region of subtropical China. Geoderma,115(1-2):0-99.

Tang M (2017) Primary Researches on Dust Retention Effects of Landscape Plants in Industrial Mining Area of Tangshan City. Hubei Agricultural Sciences, 56(19):3664-3668.

Wang B, Zhang WK, Niu X, Wang XY (2015) Particulate Matter Adsorption Capacity of 10 Evergreen Species in Beijing. Environmental Science, 36(2): 408-414. 
1 Wang F, Xiong SG, Li HY (2015) Study on dust-retention ability of major afforestation tree species in Tianjin airport economic area. Journal of Arid Land Resources and Environment, 29(1):100-104.

Wang F, Xiong SG, Li HY (2014) Study on Dust-Retention Ability of Major Afforestation Tree Species in New Industrial Zone. Advanced Materials Research, 838-841:2433-2438.

Wang HX, Wang YH, Yang J, Xie BZ, Shi (2015) Multi-Scale Comparisons of Particulate Matter and Its Size Fractions Deposited on Leaf Surfaces of Major Greening Tree Species. Scientia Silvae Sinicae,51(7): 9-20.

Wang X (2011) The effect and treatment methods of coal mining on the environment in mining areas. Coal, 20(5): 60-61,63.

Wang X, Zhu D, Wang Y, Wei X, Ma L (2015) Soil water and root distribution under jujube plantations in the semiarid Loess Plateau region, China. Plant growth regulation, 77(1), 21-31.

Wang YC (2011) Carbon sequestration and foliar dust retention by woody plants in the greenbelts along two major Taiwan highways. Annals of Applied Biology, 159(2):244-251.

Wu D (2012) Hazy weather research in China in the last decade: A review. Acta Science Circumstantiae, 32(2):257-269. 
Xie DB, Hu MX (2016) Research on the classification index system design of the stateowned forest farms based on correlation analysis and principal component analysis. Journal of Central South University of Forestry \& Technology, 36 (8):141-146.

Yu KX, Bai LL, Li ZB (2018) Dynamic evaluation of ecological benefits and weight analysis of indexes for the linear production and construction project: A case study of national highway from Xi'an to Shangluo. Science of Soil and Water Conservation, 16(4):115-123.

Zhang J, Liu H, Li XP (2014) Effect of drought on leaf physiological parameters and yield of wheat at booting stage. Agricultural Research In The Arid Areas, 32(3), $1-8$

Zhang T, Hong XL, Sun LW, Liu YJ (2017) Particle-retaining characteristics of six tree species and their relations with micro-configurations of leaf epidermis. Journal of Beijing Forestry University, 39(6):70-77.

Zhang VK, Wang B, Niu X (2015(a)). Study on the Adsorption Capacities for Airborne Particulates of Landscape Plants in Different Polluted Regions in Beijing (China), International journal of environmental research and public health. 12(8):9623-9638.

Zhang WK, Wang B, Niu X (2015(b)) Adsorption Capacity of the Air Particulate Matter in Urban Landscape Plants in Different Polluted Regions of Beijing. Environmental Science, 36(7): 2381-2388. 
1

Zhang YX (2016) Effects of coal mining on soil environment and microbial restoration in western area of China. China University of Mining and Technology.

Zhao TN, Zhang YX, Cao B, Xiao HJ, Zhang CL （2018） Eco-security Technology for Coal Mining Bases in The Northwestern Arid Desert Regions in China. Journal of soil and water conservation 32(1), 1-5.

Zheng JG (2013) Study on the Dust-Retention Capacity Resulting from Greenbelt of the Main Roads in Xuchang. Advanced Materials Research, 726-731:18051808.

Zhou WZ, Dong B, Liu JJ (2016) Method of Comprehensive Evaluation on Soil Fertility on the Basis of Weight Analysis. Journal of Irrigation and Drainage, 35(6):81-86.

Zhu ZH, Zheng WY, Zhang XK (2011) Principal component analysis and comprehensive evaluation on morphological and agronomic traits of drought tolerance in rapeseed (Brassica napus L.). Scientia Agricultura Sinica, 44(9):1775-1787. 


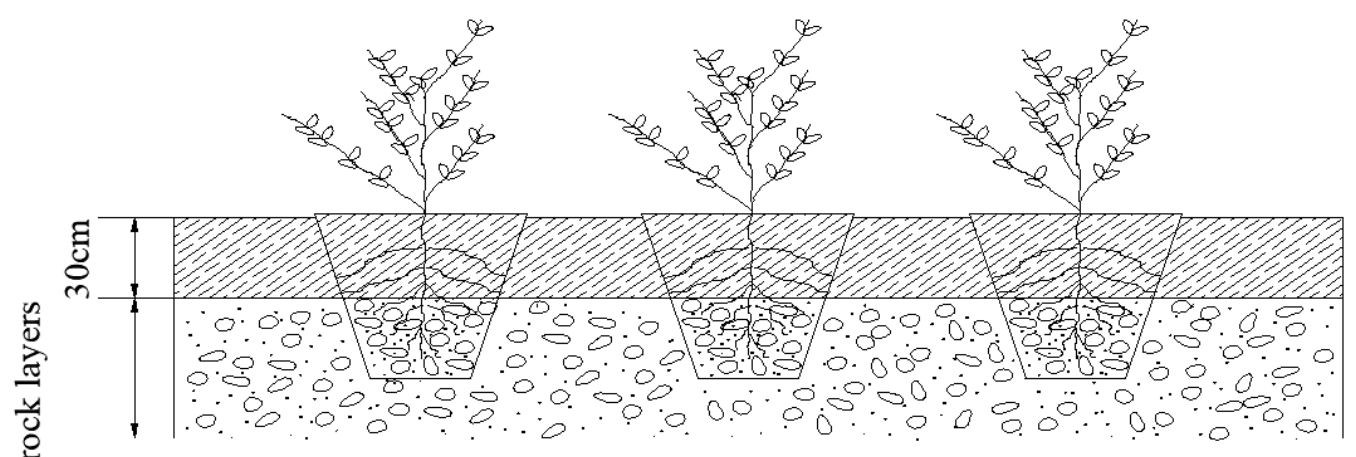

A.Dust retention test

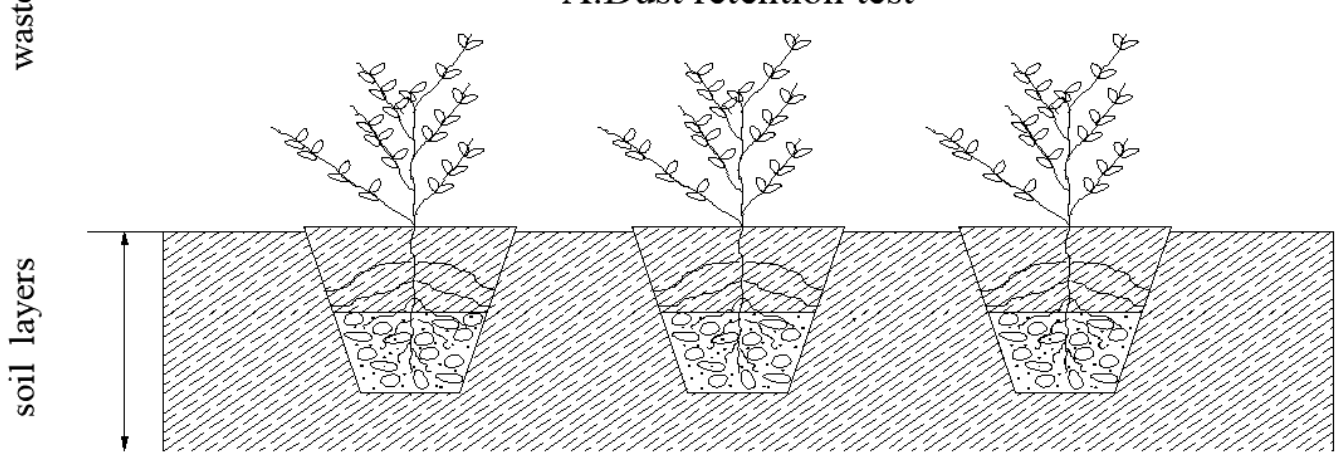

B.Drought resistant test

Fig. 1 Schematic diagram of potted planting test 
Table 1 Physicochemical properties of potted soil

\begin{tabular}{ccccccccc}
\hline Soil & $\mathrm{pH}$ & $\begin{array}{c}\text { Conductivity } \\
\left(\mathrm{ms} \cdot \mathrm{cm}^{-1}\right)\end{array}$ & $\begin{array}{c}\text { Organic } \\
\text { matter } \\
\left(\mathrm{g} \cdot \mathrm{kg}^{-1}\right)\end{array}$ & $\begin{array}{c}\text { Total } \\
\text { Nitrogen } \\
\left(\mathrm{g} \cdot \mathrm{kg}^{-1}\right)\end{array}$ & $\begin{array}{c}\text { Total Phosphorus } \\
\left(\mathrm{g} \cdot \mathrm{kg}^{-1}\right)\end{array}$ & $\begin{array}{c}\text { Alkaline } \\
\text { Nitrogen } \\
\left(\mathrm{g} \cdot \mathrm{kg}^{-1}\right)\end{array}$ & $\begin{array}{c}\text { Available } \\
\text { Phosphorus } \\
\left(\mathrm{g} \cdot \mathrm{kg}^{-1}\right)\end{array}$ \\
\hline Content & 8.81 & 1.50 & 1.97 & 0.09 & 0.11 & 41.9 & 7.69 \\
\hline
\end{tabular}

5

6

7

8

9

Table 2 Evaluation standard for Leaves under dust resistance stress

\begin{tabular}{cl}
\hline $\begin{array}{c}\text { Classification of } \\
\text { harmed leaves } \\
\text { (value) }\end{array}$ & \multicolumn{1}{c}{ Harmed symptoms } \\
\hline 0 & $\begin{array}{l}\text { Leaves were green and normal. } \\
\text { The leaves were green with individual discolored spots or slight wrinkles and } \\
\text { curls. } \\
\text { The fading area of the leaf reached } 1 / 3 \text { of the leaf area, and the leaves were } \\
\text { obviously curled. } \\
2\end{array}$ \\
$\begin{array}{l}\text { Above } 3 / 4 \text { area of the leaves were withered and severely curled. } \\
\text { The leaves were all withered or completely curled and easily broken. } \\
4\end{array}$ & Leaves fell off. \\
\hline
\end{tabular}

10

11

12

13

14

15

16

17

18

19

20

21

22

23

24

25 
2

3

4

Table 3 Symptoms of leaves after dust retention

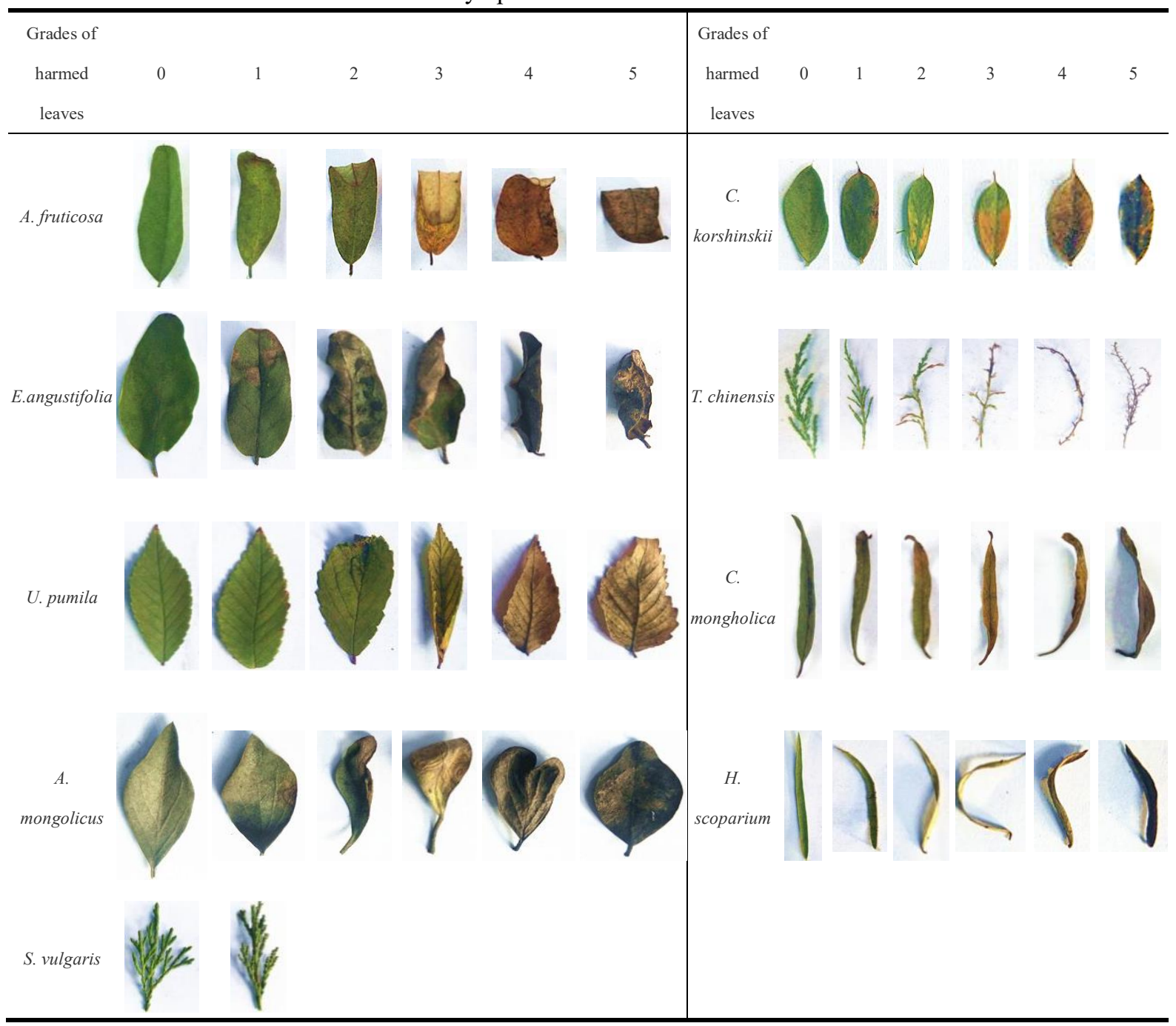

6

7

8

9

10

11

12

13

14

15

16

17

18

19 
2

3

4

5

Table 4 Tree species drought resistance evaluation index system

\begin{tabular}{|c|c|c|c|c|}
\hline Target layer & Criterion layer & Weight & Index layer & Weight \\
\hline & & & Plant height & 0.0409 \\
\hline & & & Ground diameter & 0.0162 \\
\hline & & & Shoot length & 0.0014 \\
\hline & & & Crown breadth & 0.0401 \\
\hline & Growth status index & 0.2867 & Main root length & 0.0423 \\
\hline & & & Leaf biomass ratio & 0.0041 \\
\hline & & & Stem biomass ratio & 0.0462 \\
\hline & & & Root biomass ratio & 0.0497 \\
\hline & & & Root shoot ratio & 0.0457 \\
\hline & & & Soil water content & 0.0156 \\
\hline & & & Leaf water content & 0.0159 \\
\hline & & & Plant water content & 0.0117 \\
\hline & Water physiological & 02864 & Water consumption & 0.0853 \\
\hline & index & 0.2004 & RWC & 0.0758 \\
\hline \multirow{16}{*}{$\begin{array}{c}\text { Drought resistance } \\
\text { of tree species }\end{array}$} & & & RWD & 0.0758 \\
\hline & & & Water retention capacity of & 0.0062 \\
\hline & & & leaves & \\
\hline & Adaptability index & 0.0458 & Survival rate & 0.0458 \\
\hline & & & Conductivity & 0.0598 \\
\hline & Stress resistance index & 0.1036 & MDA content & 0.0048 \\
\hline & & & Pro content & 0.0390 \\
\hline & & & Transpiration rate $\mathrm{Tr}$ & 0.0016 \\
\hline & & & Stomatal conductance Gs & 0.0140 \\
\hline & Photosynthetic & 01051 & Photosynthetic rate Pn & 0.0235 \\
\hline & physiological index & & Intercellular $\mathrm{CO}_{2}$ concentration & 00327 \\
\hline & & & (Ci) & 19.0 \\
\hline & & & Water use efficiency WUE & 0.0332 \\
\hline & & & CAT content & 0.0378 \\
\hline & Biochemical indices & 0.1724 & SOD content & 0.0620 \\
\hline & & & POD content & 0.0726 \\
\hline
\end{tabular}

6

7

8

9

10

11

12

13 
Table 5 Eigen vectors and percentages of accumulated contribution of principal components

\begin{tabular}{|c|c|c|c|c|c|c|c|}
\hline \multirow[b]{2}{*}{ Indices } & \multicolumn{7}{|c|}{ Eigenvectors of the principal component indices } \\
\hline & $\begin{array}{c}\text { Principal } \\
\text { compone } \\
\text { nt } 1\end{array}$ & $\begin{array}{c}\text { Principal } \\
\text { component } \\
2\end{array}$ & $\begin{array}{l}\text { Principal } \\
\text { component } \\
3\end{array}$ & $\begin{array}{c}\text { Principal } \\
\text { component } \\
4\end{array}$ & $\begin{array}{c}\text { Principal } \\
\text { component } \\
5\end{array}$ & $\begin{array}{c}\text { Principal } \\
\text { component } \\
6\end{array}$ & $\begin{array}{c}\text { Principal } \\
\text { component } \\
7\end{array}$ \\
\hline Plant height & -0.0296 & -0.0167 & 0.1638 & 0.0613 & 0.1840 & -0.0282 & -0.0136 \\
\hline Ground diameter & 0.0866 & -0.0408 & -0.1085 & 0.0071 & -0.0317 & -0.2381 & -0.1342 \\
\hline Shoot length & -0.0199 & 0.0631 & 0.1368 & -0.0491 & -0.1971 & -0.1282 & -0.0210 \\
\hline Crown breadth & -0.0341 & 0.0777 & 0.1458 & 0.1274 & -0.0946 & -0.0483 & 0.0953 \\
\hline $\begin{array}{c}\text { Main root system } \\
\text { length }\end{array}$ & -0.0043 & 0.1287 & 0.0336 & 0.1638 & -0.0326 & -0.2063 & 0.0148 \\
\hline $\begin{array}{c}\text { Leaf biomass } \\
\text { ratio }\end{array}$ & 0.0181 & 0.0750 & 0.0316 & -0.1306 & -0.0633 & -0.3175 & 0.1458 \\
\hline $\begin{array}{c}\text { Stem biomass } \\
\text { ratio }\end{array}$ & -0.1149 & 0.0497 & 0.0064 & -0.1165 & 0.0228 & 0.0276 & -0.0468 \\
\hline $\begin{array}{c}\text { Root biomass } \\
\text { ratio }\end{array}$ & 0.0994 & -0.0058 & -0.0080 & 0.1731 & -0.0509 & -0.0107 & -0.1089 \\
\hline Root shoot ratio & 0.0969 & -0.0124 & -0.0100 & 0.1762 & -0.0564 & -0.0161 & -0.1212 \\
\hline $\begin{array}{c}\text { Soil water } \\
\text { content }\end{array}$ & 0.0753 & -0.0253 & -0.1101 & -0.1765 & 0.0173 & -0.0136 & 0.0676 \\
\hline $\begin{array}{c}\text { Leaf water } \\
\text { content }\end{array}$ & -0.0070 & 0.1403 & -0.0899 & 0.0135 & 0.0128 & 0.1608 & -0.2665 \\
\hline $\begin{array}{c}\text { Plant water } \\
\text { content }\end{array}$ & -0.0254 & 0.1063 & -0.1661 & 0.0363 & -0.0226 & 0.0048 & 0.0746 \\
\hline $\begin{array}{c}\text { Water } \\
\text { consumption }\end{array}$ & 0.1157 & 0.0537 & 0.0518 & 0.0474 & 0.0531 & 0.0918 & -0.0497 \\
\hline RWC & 0.1075 & -0.0257 & 0.0564 & 0.0373 & 0.0954 & 0.0589 & 0.2443 \\
\hline RWD & 0.1075 & -0.0257 & 0.0564 & 0.0373 & 0.0954 & 0.0589 & 0.2443 \\
\hline $\begin{array}{c}\text { Water retention } \\
\text { capacity of } \\
\text { leaves }\end{array}$ & -0.0697 & -0.0502 & 0.0190 & 0.1622 & 0.1218 & 0.1103 & -0.2469 \\
\hline Survival rate & 0.0807 & 0.1302 & -0.0463 & -0.0422 & 0.0160 & -0.1245 & 0.0246 \\
\hline Conductivity & -0.0144 & 0.1531 & 0.0442 & 0.0744 & 0.0874 & -0.0997 & 0.1900 \\
\hline $\begin{array}{c}\text { Transpiration } \\
\text { rate } \mathrm{Tr}\end{array}$ & 0.0333 & 0.0497 & -0.1206 & 0.1346 & -0.1792 & 0.0760 & -0.0801 \\
\hline $\begin{array}{c}\text { Stomatal } \\
\text { conductance Gs }\end{array}$ & -0.0321 & 0.0560 & -0.1625 & -0.0406 & 0.0816 & 0.1121 & 0.2023 \\
\hline $\begin{array}{c}\text { Photosynthetic } \\
\text { rate Pn }\end{array}$ & -0.0825 & 0.0408 & -0.0913 & 0.1548 & -0.0599 & -0.0177 & 0.1582 \\
\hline $\begin{array}{c}\text { Intercellular } \mathrm{CO}_{2} \\
\text { concentration }\end{array}$ & 0.0763 & 0.0258 & 0.0476 & -0.0604 & -0.1902 & 0.2264 & 0.0341 \\
\hline
\end{tabular}

(Ci) 


\begin{tabular}{|c|c|c|c|c|c|c|c|}
\hline $\begin{array}{c}\text { Water use } \\
\text { efficiency WUE }\end{array}$ & -0.1255 & 0.0285 & 0.0040 & 0.0500 & 0.0190 & 0.0030 & 0.0510 \\
\hline CAT content & 0.0402 & 0.1390 & -0.0197 & -0.0786 & 0.1193 & -0.0555 & -0.2194 \\
\hline Pro content & 0.0253 & 0.0943 & 0.0280 & -0.0513 & 0.2152 & -0.0977 & -0.2859 \\
\hline SOD content & 0.0435 & 0.0949 & 0.1261 & -0.0890 & -0.0126 & 0.2195 & -0.0771 \\
\hline POD content & 0.0152 & 0.1309 & -0.0243 & 0.0457 & 0.1183 & 0.2077 & 0.2585 \\
\hline MDA content & -0.0233 & 0.0978 & 0.0796 & -0.0898 & -0.1830 & 0.1610 & -0.0808 \\
\hline $\begin{array}{c}\text { Characteristic } \\
\text { root }\end{array}$ & 7.5403 & 5.3132 & 4.5916 & 3.4607 & 3.0691 & 2.0017 & 1.5062 \\
\hline $\begin{array}{l}\text { Contribution rate } \\
\qquad(\%)\end{array}$ & 26.9298 & 18.9758 & 16.3984 & 12.3598 & 10.9612 & 7.1490 & 5.3794 \\
\hline $\begin{array}{c}\text { Cumulative } \\
\text { contribution rate } \\
(\%)\end{array}$ & 26.9298 & 45.9056 & 62.3040 & 74.6638 & 85.6250 & 92.7740 & 98.1535 \\
\hline
\end{tabular}

1

2

3

4

5

6

7

8

9

10

11

12

13

14

15

16

17

18

19

20

21

22

23

24

25

26

27

28

29

30 
1

2 Table 6 The value of each tree species' comprehensive index [C$\left.C_{x}\right]$, index weight, $U\left(X_{j}\right)$, value $D$

\begin{tabular}{|c|c|c|c|c|c|c|c|c|c|c|c|c|c|c|c|c|}
\hline Variety & $\mathrm{CI}_{1}$ & $\mathrm{CI}_{2}$ & $\mathrm{CI}_{3}$ & $\mathrm{CI}_{4}$ & $\mathrm{CI}_{5}$ & $\mathrm{CI}_{6}$ & $\mathrm{Cl}_{7}$ & $U\left(X_{I}\right)$ & $U\left(X_{2}\right)$ & $U\left(X_{3}\right)$ & $U\left(X_{4}\right)$ & $U\left(X_{5}\right)$ & $U\left(X_{6}\right)$ & $U\left(X_{7}\right)$ & $\begin{array}{c}\mathrm{D} \\
\text { value }\end{array}$ & Order \\
\hline $\begin{array}{c}\text { A. } \\
\text { mongolicus }\end{array}$ & 1.3695 & 4.3121 & 0.9762 & 1.4074 & 1.4322 & -0.7877 & -1.3474 & 0.9396 & 0.7144 & 0.4250 & 1.0000 & 0.5434 & 0.0291 & 0.3531 & 0.6750 & 1 \\
\hline H. scoparium & 1.4709 & 4.4440 & 1.3248 & 0.0949 & 1.9232 & -0.7942 & -1.7625 & 1.0000 & 0.7599 & 0.6938 & 0.0000 & 0.6758 & 0.0242 & 0.2189 & 0.6265 & 2 \\
\hline S. vulgaris & 1.4447 & 4.6920 & 0.7107 & 0.4419 & 3.2152 & -0.6770 & -2.4398 & 0.9844 & 0.8455 & 0.2203 & 0.2644 & 1.0243 & 0.1128 & 0.0000 & 0.6263 & 3 \\
\hline C.korshinskii & 1.0167 & 4.7747 & 1.0031 & 0.6277 & 0.9730 & 0.1431 & -1.8533 & 0.7295 & 0.8741 & 0.4458 & 0.4059 & 0.4196 & 0.7323 & 0.1896 & 0.6053 & 4 \\
\hline U. pumila & 0.5939 & 3.2188 & 1.7219 & 1.1715 & 0.5932 & 0.2285 & -0.4554 & 0.4778 & 0.3369 & 1.0000 & 0.8203 & 0.3171 & 0.7968 & 0.6414 & 0.5952 & 5 \\
\hline A.fruticosa & 1.4506 & 2.9369 & 0.9179 & 0.9176 & -0.5827 & -0.2004 & -0.1013 & 0.9879 & 0.2396 & 0.3801 & 0.6268 & 0.0000 & 0.4728 & 0.7559 & 0.5357 & 6 \\
\hline C.mongholica & 0.4824 & 5.1395 & 1.5973 & 0.2515 & 0.8345 & -0.8263 & -1.7280 & 0.4114 & 1.0000 & 0.9039 & 0.1193 & 0.3822 & 0.0000 & 0.2301 & 0.5276 & 7 \\
\hline T. chinensis & 0.7612 & 3.5288 & 0.4647 & 1.1120 & -0.3445 & 0.4975 & 0.6539 & 0.5774 & 0.4440 & 0.0307 & 0.7749 & 0.0643 & 1.0000 & 1.0000 & 0.4817 & 8 \\
\hline E.angustifolia & -0.2085 & 2.2428 & 0.4249 & 1.1489 & -0.5699 & 0.1084 & -0.1466 & 0.0000 & 0.0000 & 0.0000 & 0.8031 & 0.0035 & 0.7061 & 0.7413 & 0.1935 & 9 \\
\hline Weight & & & & & & & & 0.2744 & 0.1933 & 0.1671 & 0.1259 & 0.1117 & 0.0728 & 0.0548 & & \\
\hline
\end{tabular}

3

4

5

6

7

8

9

10

11

12

13

14

15

16

17

18

19

20

21

22

23 
Table 7 Tree dust resistance evaluation index system

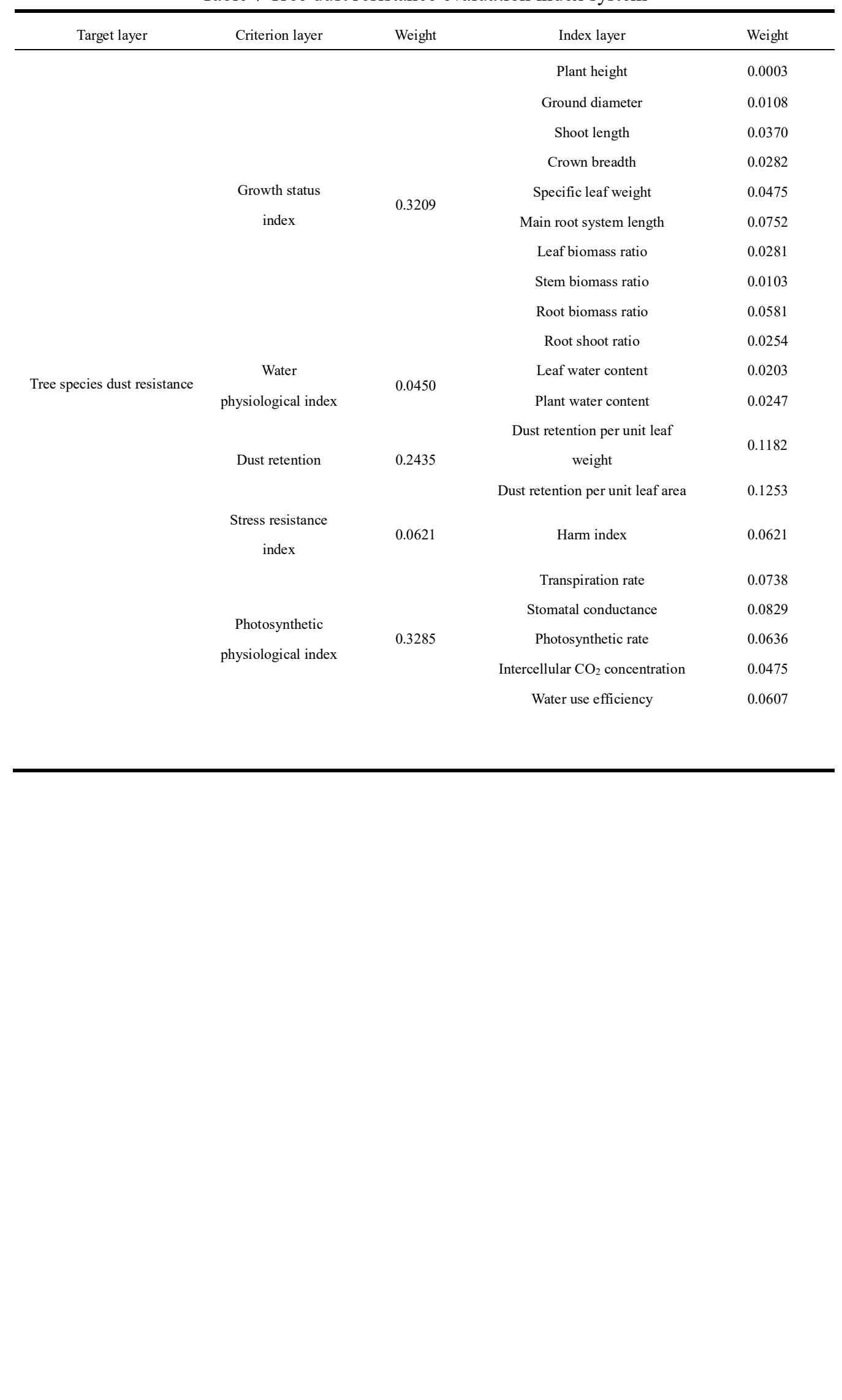



Table 8 Eigenvectors and contribution rates of principal components of each index

\begin{tabular}{|c|c|c|c|c|c|c|}
\hline \multirow[b]{2}{*}{ Indices } & \multicolumn{6}{|c|}{ Eigenvectors of the principal component indices } \\
\hline & $\begin{array}{c}\text { Principal } \\
\text { component } 1\end{array}$ & $\begin{array}{c}\text { Principal } \\
\text { component } 2\end{array}$ & $\begin{array}{c}\text { Principal } \\
\text { component } 3\end{array}$ & $\begin{array}{c}\text { Principal } \\
\text { component } 4\end{array}$ & $\begin{array}{c}\text { Principal } \\
\text { component } 5\end{array}$ & $\begin{array}{c}\text { Principal } \\
\text { component } 6\end{array}$ \\
\hline Plant height & 0.025 & -0.097 & 0.222 & -0.016 & -0.189 & -0.237 \\
\hline Ground diameter & -0.114 & 0.041 & 0.191 & -0.046 & 0.124 & -0.086 \\
\hline Shoot length & 0.121 & -0.033 & 0.115 & -0.129 & -0.221 & 0.044 \\
\hline Crown breadth & -0.007 & 0.098 & 0.144 & -0.202 & -0.116 & 0.385 \\
\hline Specific leaf weight & -0.011 & -0.087 & 0.119 & 0.126 & 0.419 & 0.013 \\
\hline Main root system length & 0.09 & -0.021 & -0.045 & 0.064 & 0.168 & 0.454 \\
\hline Leaf biomass ratio & -0.058 & -0.038 & 0.156 & 0.251 & -0.048 & 0.106 \\
\hline Stem biomass ratio & 0.124 & -0.106 & 0.003 & -0.158 & -0.08 & 0.074 \\
\hline Root biomass ratio & -0.034 & 0.241 & 0.079 & 0.035 & 0.079 & -0.115 \\
\hline Root shoot ratio & -0.056 & 0.226 & 0.065 & -0.004 & -0.019 & -0.175 \\
\hline Leaf water content & -0.01 & 0.215 & -0.101 & -0.039 & -0.131 & 0.19 \\
\hline Plant water content & 0.003 & 0.136 & -0.188 & -0.143 & 0.073 & -0.184 \\
\hline Dust retention per unit leaf weight & 0.117 & 0.15 & 0.043 & 0.114 & 0.047 & 0.046 \\
\hline Dust retention per unit leaf area & 0.123 & 0.122 & 0.034 & 0.095 & 0.146 & 0.176 \\
\hline Harm index & 0.005 & 0.071 & 0.11 & 0.277 & -0.224 & 0.081 \\
\hline Transpiration rate & 0.149 & 0.014 & 0.017 & -0.006 & 0.135 & -0.23 \\
\hline Stomatal conductance & 0.107 & 0.068 & 0.205 & -0.07 & -0.057 & -0.106 \\
\hline Photosynthetic rate & 0.085 & 0.017 & 0.145 & -0.186 & 0.26 & -0.024 \\
\hline Intercellular $\mathrm{CO}_{2}$ concentration & 0.127 & -0.02 & -0.08 & 0.172 & -0.133 & -0.111 \\
\hline Water use efficiency & -0.136 & -0.037 & 0.096 & -0.12 & 0.002 & 0.2 \\
\hline Characteristic root & 6.1 & 3.763 & 3.223 & 2.678 & 1.869 & 1.415 \\
\hline Contribution rate $(\%)$ & 30.5 & 18.816 & 16.114 & 13.391 & 9.345 & 7.074 \\
\hline Cumulative contribution rate $(\%)$ & 30.5 & 49.316 & 65.43 & 78.821 & 88.166 & 95.24 \\
\hline
\end{tabular}

3

4

5

6

7 
2 Table 9 Comprehensive index values, weights, $U(X j)$, D values and sorting of each species

\begin{tabular}{|c|c|c|c|c|c|c|c|c|c|c|c|c|c|c|}
\hline Variety & $C I_{I}$ & $\mathrm{CI}_{2}$ & $\mathrm{CI}_{3}$ & $\mathrm{CI}_{4}$ & $\mathrm{CI}_{5}$ & $\mathrm{CI}_{6}$ & $U\left(X_{l}\right)$ & $U\left(X_{2}\right)$ & $U\left(X_{3}\right)$ & $U\left(X_{4}\right)$ & $U\left(X_{5}\right)$ & $U\left(X_{6}\right)$ & $\begin{array}{c}\mathrm{D} \\
\text { value } \\
\end{array}$ & $\begin{array}{l}\text { Or } \\
\text { der }\end{array}$ \\
\hline $\begin{array}{l}\text { Caragana } \\
\text { korshinskii }\end{array}$ & 5.2477 & 1.7804 & 5.7658 & -1.6624 & -1.1033 & -0.5922 & 1.0000 & 0.3765 & 1.0000 & 0.0000 & 0.0000 & 0.1942 & 0.5782 & 1 \\
\hline $\begin{array}{l}\text { Tamarix } \\
\text { chinensis }\end{array}$ & 2.3636 & 1.8958 & 2.4664 & -0.2503 & 0.2480 & 0.5203 & 0.2224 & 0.4239 & 0.0000 & 0.7040 & 0.9054 & 0.9491 & 0.4133 & 5 \\
\hline $\begin{array}{l}\text { Hedysarum } \\
\text { scoparium }\end{array}$ & 2.1347 & 1.3665 & 4.7356 & 0.3436 & -0.3226 & -0.0822 & 0.1607 & 0.2066 & 0.6878 & 1.0000 & 0.5230 & 0.5402 & 0.4407 & 4 \\
\hline $\begin{array}{l}\text { Elaeagnus } \\
\text { angustifolia }\end{array}$ & 1.5386 & 0.8630 & 2.4808 & -0.3730 & 0.0335 & 0.2452 & 0.0000 & 0.0000 & 0.0044 & 0.6427 & 0.7616 & 0.7624 & 0.2225 & 9 \\
\hline $\begin{array}{l}\text { Caryopteris } \\
\text { mongholica }\end{array}$ & 1.7574 & 1.4006 & 2.5960 & 0.0460 & -0.3572 & -0.0290 & 0.0590 & 0.2206 & 0.0393 & 0.8516 & 0.4999 & 0.5763 & 0.2807 & 8 \\
\hline Sabina vulgaris & 2.0157 & 3.2996 & 4.5621 & -0.4719 & -0.4117 & -0.8784 & 0.1286 & 1.0000 & 0.6352 & 0.5935 & 0.4633 & 0.0000 & 0.4752 & 3 \\
\hline $\begin{array}{l}\text { Amorpha } \\
\text { fruticosa }\end{array}$ & 3.4645 & 1.7662 & 3.8878 & -0.1139 & 0.1527 & -0.6727 & 0.5192 & 0.3707 & 0.4308 & 0.7720 & 0.8415 & 0.1395 & 0.5139 & 2 \\
\hline $\begin{array}{l}\text { Ammopiptanth } \\
\text { us mongolicus }\end{array}$ & 1.7080 & 1.6452 & 3.1189 & 0.2106 & 0.3171 & 0.5954 & 0.0457 & 0.3210 & 0.1978 & 0.9337 & 0.9516 & 1.0000 & 0.4105 & 6 \\
\hline Weight & & & & & & & 0.3202 & 0.1976 & 0.1692 & 0.1406 & 0.0981 & 0.0743 & & \\
\hline $\begin{array}{l}3 \\
4 \\
5\end{array}$ & Tab & 0 Cor & rehens & e index & values, & eights, & $J(X j), \mathrm{I}$ & values & ind sor & $\mathrm{ng}$ of $\mathrm{e}$ & ch spec & ies & & \\
\hline Variety & $C I_{1}$ & $\mathrm{CI}_{2}$ & $\mathrm{CI}_{3}$ & $\mathrm{CI}_{4}$ & $\mathrm{CI}_{5}$ & $\mathrm{CI}_{6}$ & $U\left(X_{1}\right)$ & $U\left(X_{2}\right)$ & $U\left(X_{3}\right)$ & $U\left(X_{4}\right)$ & $U\left(X_{5}\right)$ & $U\left(X_{6}\right)$ & $\begin{array}{c}\mathrm{D} \\
\text { value }\end{array}$ & $\begin{array}{l}\text { Or } \\
\text { der }\end{array}$ \\
\hline U pumila & 3.0031 & 1.8346 & 3.6603 & -1.3468 & 0.3893 & -0.5618 & 0.3948 & 0.3987 & 0.3619 & 0.1573 & 1.0000 & 0.2148 & 0.4026 & 7 \\
\hline $\begin{array}{l}\text { Caragana } \\
\text { korshinskii }\end{array}$ & 5.2477 & 1.7804 & 5.7658 & -1.6624 & -1.1033 & -0.5922 & 1.0000 & 0.3765 & 1.0000 & 0.0000 & 0.0000 & 0.1942 & 0.5782 & 1 \\
\hline $\begin{array}{l}\text { Tamarix } \\
\text { chinensis }\end{array}$ & 2.3636 & 1.8958 & 2.4664 & -0.2503 & 0.2480 & 0.5203 & 0.2224 & 0.4239 & 0.0000 & 0.7040 & 0.9054 & 0.9491 & 0.4133 & 5 \\
\hline $\begin{array}{l}\text { Hedysarum } \\
\text { scoparium }\end{array}$ & 2.1347 & 1.3665 & 4.7356 & 0.3436 & -0.3226 & -0.0822 & 0.1607 & 0.2066 & 0.6878 & 1.0000 & 0.5230 & 0.5402 & 0.4407 & 4 \\
\hline $\begin{array}{l}\text { Elaeagnus } \\
\text { angustifolia }\end{array}$ & 1.5386 & 0.8630 & 2.4808 & -0.3730 & 0.0335 & 0.2452 & 0.0000 & 0.0000 & 0.0044 & 0.6427 & 0.7616 & 0.7624 & 0.2225 & 9 \\
\hline $\begin{array}{l}\text { Caryopteris } \\
\text { mongholica }\end{array}$ & 1.7574 & 1.4006 & 2.5960 & 0.0460 & -0.3572 & -0.0290 & 0.0590 & 0.2206 & 0.0393 & 0.8516 & 0.4999 & 0.5763 & 0.2807 & 8 \\
\hline Sabina vulgaris & 2.0157 & 3.2996 & 4.5621 & -0.4719 & -0.4117 & -0.8784 & 0.1286 & 1.0000 & 0.6352 & 0.5935 & 0.4633 & 0.0000 & 0.4752 & 3 \\
\hline $\begin{array}{l}\text { Amorpha } \\
\text { fruticosa }\end{array}$ & 3.4645 & 1.7662 & 3.8878 & -0.1139 & 0.1527 & -0.6727 & 0.5192 & 0.3707 & 0.4308 & 0.7720 & 0.8415 & 0.1395 & 0.5139 & 2 \\
\hline $\begin{array}{l}\text { Ammopiptanth } \\
\text { us mongolicus }\end{array}$ & 1.7080 & 1.6452 & 3.1189 & 0.2106 & 0.3171 & 0.5954 & 0.0457 & 0.3210 & 0.1978 & 0.9337 & 0.9516 & 1.0000 & 0.4105 & 6 \\
\hline Weight & & & & & & & 0.3202 & 0.1976 & 0.1692 & 0.1406 & 0.0981 & 0.0743 & & \\
\hline
\end{tabular}


1

2 The datasets used and/or analyzed during the current study are available from the

3 corresponding author on reasonable request.

4

\section{Abbreviations}

$6 \quad$ PCA method Principal component analysis method

$\begin{array}{lll}7 & \mathrm{SO}_{2} & \text { Sulfur dioxide }\end{array}$

$8 \quad \mathrm{NO}_{\mathrm{x}} \quad$ Nitric oxide

9 SOD Superoxide dismutase

10 POD Peroxidase

11 CAT Catalase

$12 \quad \mathrm{CO}_{2} \quad$ Carbon dioxide

13

14

15

16

17

18

19

20

21

22

23

\section{$24 \quad$ Funding}

25 This work was supported by the National Key Research and Development Program - 
Research on vegetation reconstruction and protection for coal mining bases in the northwestern Arid desert region (2017YFC0504402).

\section{Author information}

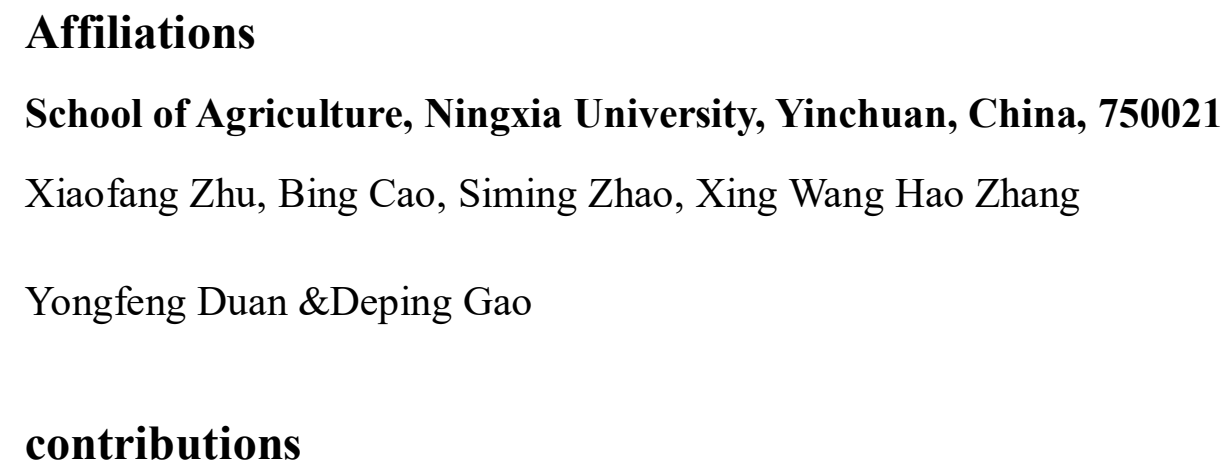
collected data. Yongfeng Duan and Deping Gao provided field assistants. Xiaofang Zhu wrote the paper, Bing Cao and Xing Wang reviewed the paper. All authors read and approved the final manuscript.

\section{Corresponding author}

Correspondence to Bing $\mathrm{Cao}^{1}$ and Xing Wang $^{2}$

\section{Ethics declarations}

Ethics approval and consent to participate

Not applicable.

Consent for publication 
1 Not applicable.

\section{Competing interests}

3 The authors declare that they have no competing interests.

4 


\section{Figures}

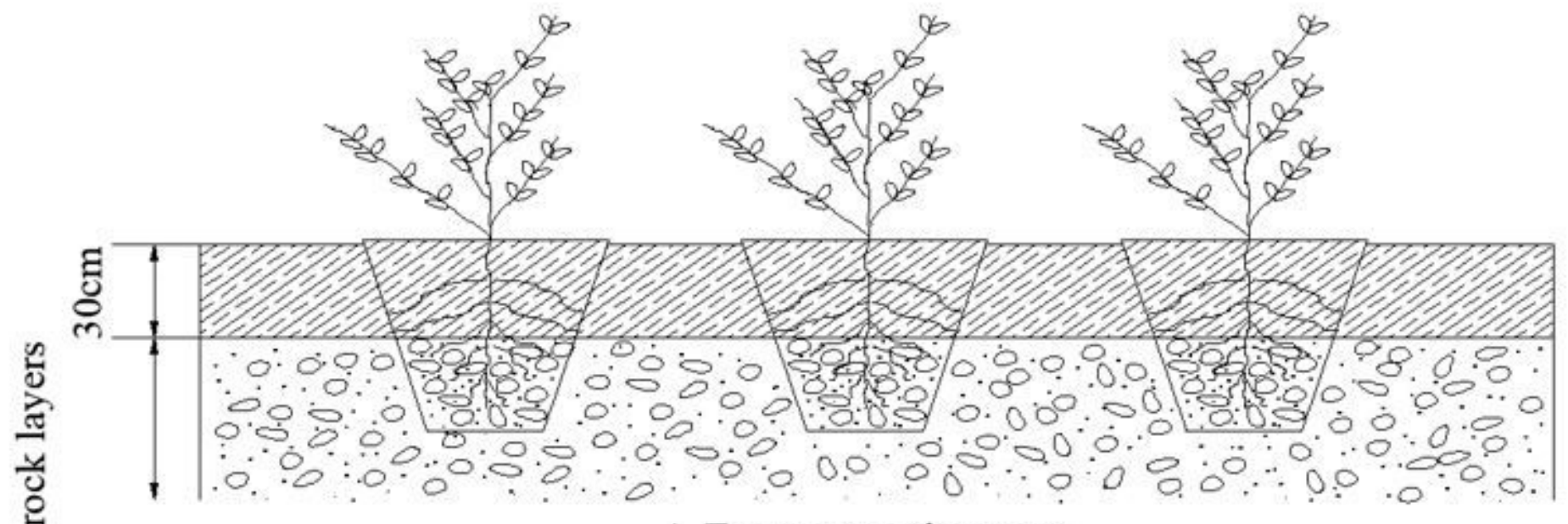

\section{A.Dust retention test}

$\frac{1}{3}$
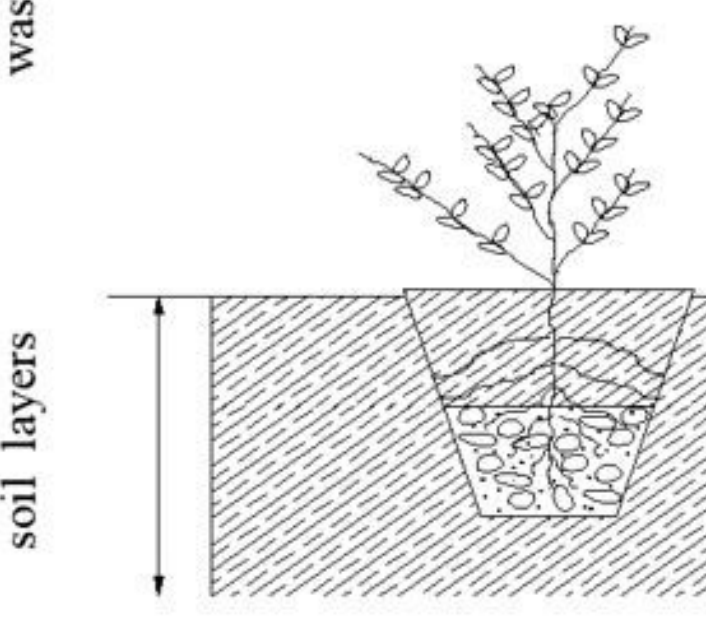

\section{B.Drought resistant test}

\section{Figure 1}

Schematic diagram of potted planting test 